\title{
PENGARUH ETIKA GURU TERHADAP AKHLAK SISWA
}

(Studi di Madrasah Tsanawiyah Rihlatul Ummah Cilegon)

\author{
Is Nurhayati, Novi Tria Rahmawati \\ STIT Al-Khairiyah Cilegon \\ isnurhayati87@gmail.com,novitria639@gmail.com
}

\begin{abstract}
Ethics restrictions of human behavior. All forms of his actions cling to the norm. Ethics is very important for everyone, because if without ethics then someone will arbitrary without thinking of consequences that will be caused after the event. Teacher ethics is very instrumental in the formation of student behavior in school and in environment. This research aiming to know teacher ethics at MTs Rihlatul Ummah. To know moral students at MTs Rihlatul Ummah. To know the influence of teacher ethics on student morals at MTs Rihlatul Ummah. Data collection technique used through observation and questionnaire. Data collected analyzed using statistical approach product moment correlation. Result of research is there is a positive influence and significant between teacher ethics with student morals at MTs Rihlatul Ummah with the level of the correlation coeffesient in the amount of 0,78 (strong). This matter proven with degree of significance that is at $t_{\text {tabel }}$ the level significance $5 \%$ in the amount of 1,67 and $t_{\text {hitung }}$ 10,64 which means $t_{\text {hitung }}>t_{\text {tabel. }}$. As for contribution variable $X$ with variable $Y$ in the amount of $61 \%$, the meaning $61 \%$ student morals at MTs Rihlatul Ummah associated with teacher ethics.
\end{abstract}

Keywords: Teacher Ethics, Student Morals, Product Moment Correlation.

\section{Abstrak}

Etika merupakan batasan-batasan terhadap tingkah laku manusia. Segala bentuk perbuatannya berpegang teguh pada norma. 
Etika sangat penting bagi setiap orang, karena jika tanpa adanya etika maka seseorang akan berlaku sewenang-wenang tanpa memikirkan akibat yang akan ditimbulkan setelah peristiwa tersebut. Etika guru sangat berperan dalam pembentukan tingkah laku siswanya di sekolah dan di lingkungannya. Penelitian ini bertujuan untuk mengetahui etika guru di MTs Rihlatul Ummah. Untuk mengetahui akhlak siswa di MTs Rihlatul Ummah. Untuk mengetahui pengaruh etika guru terhadap akhlak siswa di MTs Rihlatul Ummah. Teknik pengumpulan data yang digunakan melalui observasi dan penyebaran angket. Data yang terkumpul dianalisis menggunakan pendekatan analisis korelasi product moment. Hasil dari penelitian ini membuktikan adanya pengaruh yang positif dan signifikan antara etika guru dengan akhlak siswa di MTs Rihlatul Ummah dengan tingkat koefisien korelasi sebesar 0,78 (kuat). Hal ini terbukti dengan derajat signifikansi yaitu $t_{\text {tabel }}$ pada taraf signifikansi $5 \%$ sebesar 1,67 dan $t_{\text {hitung }} 10,64$ yang berarti $t_{\text {hitung }}>t_{\text {tabel }}$. Adapun kontribusi variable $\mathrm{X}$ dengan variable $\mathrm{Y}$ sebesar $61 \%$, artinya 61\% akhlak siswa di MTs Rihlatul Ummah berhubungan dengan etika guru.

Kata kunci: Etika Guru, Akhlak Siswa, Analisis Korelasi Product Moment.

\section{PENDAHULUAN}

Etika merupakan batasan-batasan terhadap tingkah laku manusia. Seseorang yang mengerti tentang etika akan memilih dan memilah perbuatan-perbuatan yang baik atau buruk sesuai dengan norma yang berlaku. Segala bentuk perbuatannya berpegang teguh pada norma. Etika menurut filsafat ialah ilmu yang menyelidiki, mana yang baik dan mana yang buruk dengan memperhatikan amal perbuatan manusia sejauh yang dapat diketahui oleh akal pikiran. ${ }^{1}$ Etika sangat penting bagi setiap orang, karena jika tanpa adanya etika maka seseorang akan berlaku sewenang-wenang tanpa memikirkan akibat

1 Mustofa, Akhlak Tasawuf, (Bandung: CV Pustaka Setia, 2010), Cet, ke-5, hal. 15 
yang akan ditimbulkan setelah peristiwa tersebut. Menurut para ahli, etika adalah aturan perilaku, adat kebiasaan manusia dalam pergaulan antar sesamanya dan menegaskan mana yang benar dan mana yang buruk. Perkataan etika atau lazim juga disebut etik, berasal dari kata Yunani ethos yang berarti norma-norma, nilai-nilai, kaidah-kaidah dan ukuran-ukuran bagi tingkah laku manusia yang baik. ${ }^{2}$

Guru adalah pahlawan tanpa tanda jasa. Banyak orang yang sukses berkat jasa seorang guru. Guru juga merupakan orangtua di sekolah. Etika guru sangat berperan dalam pembentukan tingkah laku siswanya di sekolah dan di lingkungannya. Oleh sebab itu bagaimana etika seorang guru di sekolah akan di contoh oleh peserta didiknya, karena guru merupakan suri tauladan yang baik. Menurut Faizal Djabidi, banyak guru mengajar terkadang tidak memahami tentang manajemen dalam kegiatan belajar mengajar di kelas, dalam mindsetnya hanya berkutat pada cara yang tepat untuk menyampaikan materi sebagai tanggung jawab moral dalam mencerdaskan peserta didiknya. ${ }^{3}$ Pada kenyataannya masih ada anggapan di masyarakat bahwa siapapun dapat mengajar tanpa merasa perlu untuk mendalami ilmu mengajar. Ada saja guru yang tidak mengerti tentang etika mengajar. Tidak jarang terjadi kekerasan terhadap siswa, jika guru merasa siswanya telah melakukan kesalahan. Seharusnya seorang guru itu memiliki sifat-sifat yang baik seperti sabar, lemah lembut, penyayang dan lain sebagainya. Sebagaimana firman Allah SWT dalam Al-Qur'an surah Thaha/20 ayat 44:

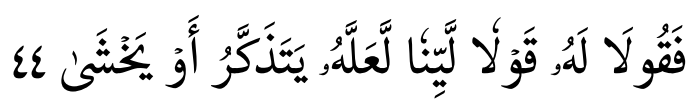

Artinya: "Maka berbicaralah kamu berdua kepadanya (Fir'aun) dengan kata-kata yang lemah lembut, mudah-mudahan dia sadar atau takut." (QS. Thaha [20]: 44)

2 Ondi Saondi dan Aris Suherman, Etika Profesi Keguruan, (Bandung: PT Refika Aditama, 2010), hal. 90

3 Faizal Djabidi, Manajemen Pengelolaan Kelas, (Malang: Madani, 2016), hal. 35

4 El-Qurtuby, Usman, Andi Subarkah, 2012, Al-Qur'an \& Terjemah Tajwid, Bandung: Cordoba. 
Seorang guru harus bertutur katalah dengan lemah lembut sesuai dengan firman Allah tersebut agar siswanya menjadi sadar dan takut tanpa adanya tindak kekerasan terhadap siswa yang melakukan kesalahan. Sehingga tingkah laku seorang guru haruslah mencerminkan tingkah laku yang baik-baik agar siswanya pun mencontoh hal tersebut. Karena adanya kode etik, maka seorang guru tidak bisa berbuat sewenang-wenang terhadap siswanya. Ada sanksi yang diberikan apabila seorang guru melanggar kode etik tersebut. Menjadi guru tidaklah mudah, karena seorang guru memiliki kode etik. Kode etik itulah yang menjadi landasan agar menjadi guru professional.

Menurut Ahmad Amin bahwa yang disebut akhlak ialah kehendak yang dibiasakan. ${ }^{5}$ Artinya bahwa suatu kehendak itu dilakukannya berulang-ulang tanpa adanya pemikiran. Karena pada hakekatnya, akhlak ialah sifat yang tertanam dalam jiwa yang menghasilkan perbuatan tanpa pemikiran (reflex). Oleh sebab itu segala perbuatan baik atau buruk yang dilakukan oleh seseorang yang dalam hal ini adalah siswa, merupakan wujud dari akhlaknya. Karena sering dilakukan akan menjadi kebiasaan. Maka kebiasaan yang baik akan mengahasilkan akhlak yang baik. Sebaliknya, kebiasaan yang buruk akan menghasilkan akhlak yang buruk pula.

Peserta didik adalah anak, individu, yang tergolong dan tercatat sebagai siswa di dalam satuan pendidikan. ${ }^{6}$ Dalam hal ini siswa di tingkat satuan pendidikan PAUD, TK, SD, SMP/MTs, maupun SMA/MA. Akan tetapi, pada penelitian ini peserta didik yang akan dibahas ialah siswa yang sedang berada di tingkat satuan pendidikan SMP/MTs. Dan tingkat satuan pendidikan yang dijadikan sebagai objek penelitian ialah Madrasah Tsanawiyah (MTs) Rihlatul Ummah. Hal ini berdasarkan dari cara berbicara siswa-siswi di sekolah tersebut terhadap temannya yang kurang sopan serta cara berpakaian yang kurang rapi dan tidak mentaati tata tertib sekolah, maka penulis tertarik untuk meneliti permasalahan "pengaruh etika guru terhadap akhlak siswa".

5 Mustofa, Akhlak Tasawuf, Op. Cit., hal. 13

6 Enung Fatimah, Psikologi Perkembangan, (Bandung: CV Pustaka Setia, 2010), Cet ke-3, hal. 12 
Berdasarkan latar belakang diatas, maka rumusan masalah penelitian ini adalah pertama, bagaimana etika guru di MTs Rihlatul Ummah Cilegon? Kedua, bagaimana akhlak siswa di MTs Rihlatul Ummah Cilegon? Dan ketiga, apakah ada pengaruh etika guru terhadap akhlak siswa di MTs Rihlatul Ummah Cilegon?

\section{METODE PENELITIAN}

Penentuan besaran sampel harus menggunakan rumus yang benar, konsisten dan memegang acuan tingkat kepercayaan yang diinginkan dan ketepatan pengambilan sampel. ${ }^{7}$ Metode pengambilan sampel menggunakan metode Slovin diperoleh sampel sebesar 75 siswa. Adapun analisis yang digunakan untuk mengetahui pengaruh antara variabel $\mathrm{X}$ tentang Etika Guru dengan variabel $\mathrm{Y}$ tentang Akhlak Siswa yaitu dengan analisis korelasi product moment. Sedangkan teknik pengumpulan data yang dilakukan dengan cara memberi seperangkat pertanyaan atau pernyataan tertulis kepada responden untuk dijawabnya. ${ }^{8}$ Teknik angket ini dilakukan dengan cara memberikan sejumlah pertanyaan kepada responden yaitu siswa-siswi MTs Rihlatul Ummah dalam bentuk jawaban tertutup.

\section{LANDASAN TEORITIS}

\section{1) Etika Guru}

\section{1) Pengertian Etika Guru}

Menurut Webster's Sirct sebagaimana yang dikutip oleh Mustofa mendefinisikan bahwa etika ialah ilmu tentang tingkah laku manusia prinsip-prinsip yang disistimatisir tentang tindakan moral yang betul. Ada orang yang berpendapat bahwa etika sama dengan akhlak. Persamaan itu memang ada, karena keduanya membahas masalah baik buruknya tingkah laku manusia. Akan tetapi, etika menurut filsafat ialah ilmu yang menyelidiki, mana yang baik dan mana yang buruk dengan memperhatikan amal perbuatan manusia sejauh yang dapat diketahui oleh akal pikiran. Sedangkan akhlak ialah tabiat atau sifat seseorang,

7 A. Muri Yusuf, Mrtode Penelitian Kuantitatif Kualitatif dan Penelitian Gabungan, (Jakarta: Kencana, 2014), hal. 170

8 Ibid,. hal. 199 
yakni keadaan jiwa yang telah terlatih, sehingga dalam jiwa tersebut benar-benar telah melekat sifat-sifat yang melahirkan perbuatanperbuatan dengan mudah dan spontan tanpa dipikirkan dan dianganangan lagi. ${ }^{9}$

Karakteristik etika dalam Islam, yaitu sebagai berikut:

1) Etika Islam mengajarkan dan menuntun manusia pada tingkah laku yang baik dan menjauhkan diri dari tingkah laku yang buruk.

2) Etika Islam menetapkan bahwa sumber moral, ukuran baikburuknya perbuatan didasarkan pada ajaran Allah SWT. (AlQur'an) dan ajaran Rasul-Nya (Sunnah).

3) Etika Islam bersifat universal dan komprehensif, dapat diterima oleh seluruh umat manusia dalam segala waktu dan tempat.

4) Dengan rumus-rumus yang praktis dan tepat, sesuai dengan fitrah (naluri) dan akal pikiran manusia, etika Islam dapat dijadikan pedoman oleh seluruh manusia.

5) Etika Islam mengatur dan mengarahkan fitrah manusia pada jenjang akhlak yang luhur dan meluruskan perbuatan manusia di bawah pencaran sinar petunjuk Allah SWT. menuju keridaanNya, sehingga terselamatkanlah manusia dari pikiran dan perbuatan yang keliru dan menyesatkan. ${ }^{10}$

Tugas guru bukan hanya sekedar mengajarkan kepada siswa dari yang tidak bisa apapun menjadi bisa. Akan tetapi seorang guru juga bertugas mendidik, membimbing, mengarahkan, melatih, menilai, dan mengevaluasi siswanya. Seorang guru jangan merasa acuh tak acuh kepada siswanya, karena sudah memberikan materi yang akan dipelajari maka beliau merasa sudah melaksanakan tugas dan tanggung jawabnya sebagai guru. Guru dijadikan contoh oleh siswanya, maka seorang guru dapat memberikan contoh teladan yang baik untuk siswanya.

Contoh teladan adalah salah satu metode yang tidak diucapkan, tetapi dapat dilihat oleh peserta didik sebagai sesuatu yang layak untuk

9 Mustofa, Akhlak Tasawuf, Op.Cit., hal. 15.

10 Rosihon Anwar, Akhlak Tasawuf, (Bandung: CV Pustaka Setia, 2010), hal. 17 
ditiru; misalnya cara berpakaian, bertutur kata, dan sikap sehari-hari seorang pendidik. ${ }^{11}$ Seorang guru harus bisa berpakaian yang baik dan sopan agar siswanya pun dapat mencontoh hal baik tersebut. Kemudian harus bisa bertutur kata dengan lemah lembut supaya siswanya pun tidak merasa takut apabila ingin bertanya suatu hal yang tidak dimengerti. Selain contoh teladan adapula metode nasihat, dimana metode ini merupakan perkataan seorang pendidik kepada peserta didiknya.

Allah SWT berfirman:

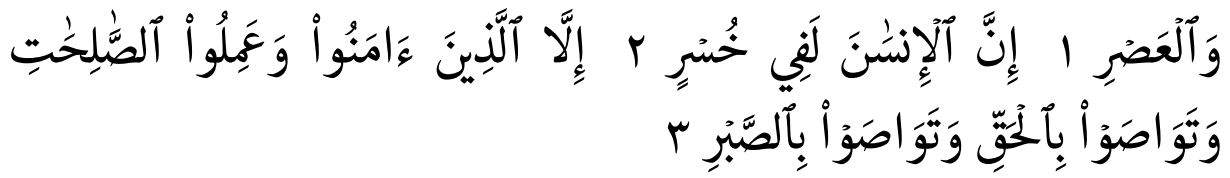

Artinya: "Demi masa. Sesungguhnya manusia itu benar-benar dalam kerugian. Kecuali orang-orang yang beriman dan mengerjakan amal saleh dan nasehat menasehati supaya mentaati kebenaran dan nasehat menasehati supaya menetapi kesabaran". (QS. al-'Ashr [103]: 1-3) ${ }^{12}$

Pada prinsipnya seorang pendidik merupakan pemberi nasihat, bertugas membentuk kepribadian seseorang. Di dalam membentuk kepribadian itu unsur utamanya adalah pembentukan jiwa. Di sini yang sangat diperlukan adalah transfer of value, pentransferan nilai-nilai. Nilai-nilai yang baik yang belum dikenal oleh peserta didik dimasukan ke dalam jiwanya, atau penguatan nilai-nilai yang baik juga bagian dari ini.

Etika guru terhadap siswa merupakan konsep kecintaan guru kepada siswanya. Rasa kecintaan tersebut akan melahirkan kelembutan dan kebijaksanaan, sabar, murah hati, kemudahan dalam mengajar serta semangat dan kekuatan, rela berkorban, perhatian dan penghargaan, adil, senang membantu, keramahan dan kasih sayang. ${ }^{13}$ Etika guru

$11 \mathrm{Ibid}$, hal. 125

12 El-Qurtuby, Usman, Andi Subarkah, 2012, Al-Qur'an \& Terjemah Tajwid, Bandung: Cordoba.

13 Suparta Munzier, Metodologi Pengajaran Agama Islam, (Jakarta:

Aniscol, 2003), hal. 2 
terhadap siswa yaitu suatu adat kebiasaan atau akhlak seorang guru yang memiliki tanggung jawab membentuk karakter anak didik yang masih memerlukan bimbingan dan arahan. ${ }^{14}$

\section{2) Tanggung Jawab Pendidik}

Tanggung jawab ini merupakan kewajiban menanggung, memelihara dan memberi latihan berupa pengajaran, mengenai akhlak dan kecerdaasan pikiran. Seorang pendidik memiliki tanggung jawab atas peserta didiknya bagaimana mengarahkannya menuju kedewasaan, baik secara akal, mental, maupun moral, untuk menjalankan fungsi kemanusiaan yang diemban sebagai seorang manusia. Berikut ini tanggung jawab pendidik:

a. Tanggung Jawab Ilmiah ${ }^{15}$

Sebagai seorang pendidik, terutama pendidik formal (guru), memiliki tanggung jawab keilmuan, yakni menyampaikan ilmunya kepada peserta didik. Dalam hal ini pendidik tidak boleh kikir untuk memberikan ilmu apalagi menyembunyikan ilmu. Di samping itu juga dia harus selalu menambah ilmunya, tidak boleh berhenti memberi dan menerima ilmu. Di dalam menyampaikan ilmu ini ada jadwal yang telah ditetapkan.

b. Tanggung Jawab Moral ${ }^{16}$

Salah satu tugas pendidik ialah membentuk manusia berakhlakul karimah, memberikan dan menerapkan nilainilai baik kepada peserta didiknya.

c. Tanggung Jawab Professiona ${ }^{17}$

Pendidik yang professional adalah pendidik yang berpikir, bekerja dan berprilaku berdasarkan prinsip dan aturan profesionalisme.

14 http://www.makalahku.online/2017/03/hadis-tentang-etika-guru-terhadapsiswa.html. Oleh Imam As'Ari (1403916165). Dikutip pada tanggal 07 Juli 2018 pukul 21.20 WIB

15 Haidar Putra Daulay, Pendidikan Islam Dalam Perspektif Filsafat, (Jakarta: Kencana, 2014), hal. 106

16 Ibid., hal. 107

17 Ibid., 
Prinsip profesionalisme itu mencakup:

1) Bekerja berlandaskan aturan yang telah ditetapkan

2) Disiplin

3) Bekerja keras

4) Loyalitas kepada tugas

5) Objektif

6) Bekerja cerdas

\section{3) Sifat-sifat Pendidik}

Tidak ada pekerjaan yang lebih mulia daripada pekerjaan sebagai pendidik, semakin tinggi dan bermanfaat materi ilmu yang diajarkannya, maka yang mengajarkannya juga semakin mulia dan tinggi derajatnya. Mengenai bagaimana sifat pendidik yang seharusnya, kita bisa bercermin pada Rasulullah SAW sebagai suri tauladan yang baik bagi umat Islam. Dalam buku yang berjudul Pendidikan Islam Dalam Perspektif Filsafat karangan Haidar Putra Daulay, ada beberapa sifat yang harus dimiliki oleh pendidik, diantaranya:

a. Ikhlas $^{18}$

Ikhlas artinya suci, bersih, sesuatu yang tidak ternoda. Surah Al-Ikhlas adalah surah yang membersihkan Allah dari beranak dan diperanakkan. Amal yang ikhlas adalah amal yang tertuju kepada Allah semata-mata, tidak ada pamrih kepada selain Allah. Gambaran inilah yang disebut dalam surah al-Bayyinah ayat 5:

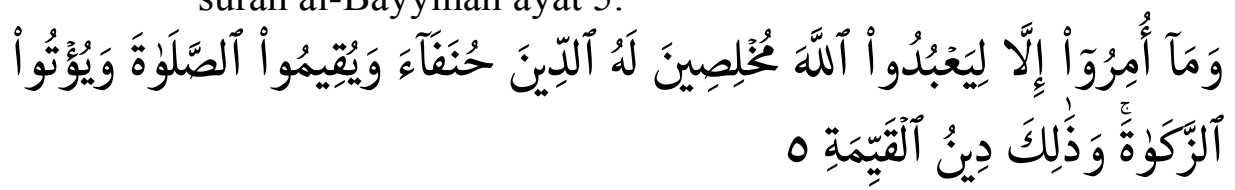

Artinya: "Padahal mereka tidak disuruh kecuali supaya menyembah Allah dengan memurnikan ketaatan kepada-Nya dalam (menjalankan) agama yang lurus, dan supaya mereka mendirikan shalat dan menunaikan zakat; dan yang demikian itulah agama yang lurus". (QS. al-Bayyinah [98]: 5) ${ }^{19}$

18 Haidar Putra Daulay, Pendidikan Islam Dalam Perspektif Filsafat,

(Jakarta: Kencana, 2014), hal. 107 
Sang guru, memulai niatnya dengan ikhlas, agar semuanya menjadi tampak menarik dan indah. Ikhlas bukanlah bermakna gratis, yaitu seorang yang telah mengajar dari pagi sampai sore, lalu dia tidak mendapat imbalan berupa gaji atau honor, gambaran seperti itulah yang dimaksud dengan ikhlas, tentu ini persepsi yang keliru. Seseorang tidak salah menerima imbalan yang wajar dan bahkan itu sesuatu yang wajar normal, tetapi yang salah itu mengedepankan dalam pikiran dan perilaku tentang uang. Belum lagi bekerja atau sedang bekerja yang selalu terbayang dan memotivasi dirinya pada materi. Seorang guru teladan, tidak demikian pikirannya, yang diutamakannya ialah kerja dan semangat bekerja, dan setelah dia bekerja, maka dia layak memperoleh imbalan.

b. Cinta $^{20}$

Cinta adalah penggerak utama kreativitas manusia dalam hidup. Pernah kita saksikan seorang ayah berhujan dan berpanas bekerja di sawah atau di lading dengan dorongan cintanya kepada anak dan istrinya guna memenuhi kebutuhan hidup mereka. Dengan dorongan cinta pula seorang rela berkorban demi yang dicintainya. Seorang guru mestilah mencintai muridnya, guru menjadikan muridnya seperti anak kandungnya sendiri. Seorang guru yang mencintai muridnya akan mengharapkan bahwa sang murid akan sukses. Cinta sang gurulah yang akan melahirkan semangat mengajar guru, kelembutan hati, kasih sayang, motivator, kerelaan berkorban, mengedepankan kesuksesan murid. Dari cinta sang guru inilah lahirnya berbagai sifat dan sikap baik lainnya. Dari cinta sang guru inilah lahir kepedulian.

19 El-Qurtuby, Usman, Andi Subarkah, 2012, Al-Qur'an \& Terjemah Tajwid, Bandung: Cordoba.

20 Haidar Putra Daulay, Pendidikan Islam Dalam Perspektif Filsafat, Op.Cit., hal. 109 
c. Teladan ${ }^{21}$

"Ulama adalah pewaris Nabi." (Riwayat an-Najjar), Nabi menjadi panutan, contoh teladan, maka guru juga menjadi panutan. Keteladanan memiliki posisi penting dalam dunia pendidikan. Seorang peserta didik termotivasi berakhlak baik, karena dia melihat contoh teladan yang baik pula. Keteladanan adalah "guru" yang diam. Ia akan memasuki relung hati sang murid, dan dihadapan matanya ada sosok yang diidolakannya. Apabila keteladanan musnah, maka sesungguhnya bangsa dan kaum itu sedang berada dalam krisis yang luar biasa.

Guru-guru sebagai pendidik, dengan wibawanya dalam pergaulan membawa murid sebagai anak didik kearah kedewasaan. Memanfaatkan pergaulan sehari-hari dalam pendidikan merupakan cara yang paling baik dan efektif dalam pembentukan pribadi dan dengan cara ini pula maka hilanglah jurang pemisah antara guru dan anak didik. ${ }^{22}$

d. Objektif ${ }^{23}$

Membenarkan yang benar dan menyalahkan yang salah, itulah gambaran dari sifat dan sikap objektif. Sikap ini adalah sikap yang berasal dari sikap jujur dan benar. Di sini akan dilihat aplikasinya tidak pilih kasih.

e. Emosi stabil24

Praktiknya dalam kehidupan sehari-hari guru dapat mengendalikan dirinya. Dapat dimaklumi bahwa tingkah laku peserta didik bermacam-macam, di antara mereka ada saja yang menjengkelkan guru. Di sinilah ditutut kematangan emosi dan kestabilannya.

21 Ibid., hal. 110

22 Hasbullah, Dasar-Dasar Ilmu Pendidikan, (Jakarta: PT RajaGrafindo Persada, 2012), Cet ke 10, hal. 116

23 Haidar Putra Daulay, Pendidikan Islam Dalam Perspektif Filsafat, Op.Cit., hal. 111

24 Ibid., 
f. Tawadhu' ${ }^{25}$

Tawadhu' adalah sifat rendah hati, lawannya sombong. Allah mencintai orang yang tawadhu' dan membenci kesombongan. Guru yang rendah hati adalah guru yang rela menerima kebenaran dari mana pun datangnya, walaupun itu dari muridnya, mungkin ada pendapat, saran dan pemikiran muridnya yang cemerlang dan bagus, maka tanpa merasa kehilangan wibawa sang guru dengan ikhlas menerimanya. Begitu juga ketika mengajar mungkin ada kebenaran ilmu yang disampaikan muridnya, maka sang guru tidak merasa malu untuk mengakuinya.

g. Qanaah (Tidak Materialistis) ${ }^{26}$

Sikap yang diambil oleh guru dalam hal ini tidak menggadaikan prinsip akhlakul karimahnya. Sang guru harus tegar mengedepankan prinsip hidup qanaah. Banyak cara yang dapat ditempuh oleh guru yang materialistik untuk memperoleh penghasilan yang tidak halal, tetapi itu tidak dilakukannya. Prinsip seperti inilah yang disebut dengan prinsip qanaah.

\section{2) Akhlak Siswa}

\section{Pengertian Akhlak Siswa}

Menurut Al-Ghazali akhlak adalah sifat yang tertanam pada jiwa yang menimbulkan perbuatan dengan mudah tanpa memerlukan pemikiran dan pertimbangan. ${ }^{27}$ Maksud perbuatan yang dilahirkan dengan mudah tanpa pikir lagi disini bukan berarti bahwa perbuatan tersebut dilakukan dengan tidak sengaja atau tidak dikehendaki. Jadi perbuatan-perbuatan yang dilakukan itu benar-benar sudah merupakan “azimah", yakni kemauan yang kuat tentang sesuatu perbuatan, oleh karenanya jelas perbuatan itu memang sengaja dikehendaki adanya. Hanya saja karena keadaan yang demikian itu dilakukan secara kontinyu, sehingga sudah menjadi adat atau kebiasaan untuk

25 Ibid., hal. 112

26 Ibid., hal. 113

27 Ibid., hal. 133 
melakukannya, dan karenanya timbullah perbuatan itu dengan mudah tanpa dipikir lagi. ${ }^{28}$

Menurut Undang-Undang No. 20 Tahun 2003 menyebutkan bahwa peserta didik adalah anggota masyarakat yang berusaha mengembangkan potensi diri melalui proses pembelajaran yang tersedia pada jalur, jenjang, dan jenis pendidikan tertentu (Bab 1 Pasal 1, ayat 4). ${ }^{29}$ Dengan demikian, akhlak siswa merupakan segala perbuatan atau tingkah laku yang dilakukan dengan refleks (spontan) oleh siswa dan dilakukan secara terus menerus sehingga menjadi kebiasaan dari diri siswa tersebut.

Selain akhlak yang baik yang harus dimiliki siswa, adapula kode etik yang harus diikuti oleh seorang siswa diantaranya:

a. Membersihkan hati dari kotoran.

b. Meluruskan niat.

c. Menghargai waktu.

d. Menjaga kesederhanaan makan dan pakaian.

e. Membuat jadwal kegiatan yang ketat.

f. Menghindari makan terlalu banyak.

g. Bersifat wara', mengurangi mengonsumsi makanan yang menyebabkan kebodohan dan kelemahan.

h. Meminimkan waktu tidur, tetapi tidak mengganggu kesehatan.

i. Membatasi pergaulan, hanya dengan orang yang bisa bermanfaat bagi belajar. ${ }^{30}$

Setiap perilaku manusia didasarkan atas kehendak. Apa yang telah dilakukan oleh manusia timbul dari kejiwaan. Walaupun pancaindera kesulitan melihat pada dasar namun dapat dilihat dari wujud kelakuan. Maka setiap kelakuan pasti bersumber dari kejiwaan. Ada beberapa aspek yang mempengaruhi bentuk akhlak, diantaranya:

a. Insting

28 Mustofa, Akhlak Tasawuf, (Bandung: CV. Pustaka Setia, 2010), hal. 15

29 Haidar Putra Daulay, Pendidikan Islam Dalam Perspektif Filsafat, Op. Cit., hal. 115

30 Ibid., hal. 120 
Menurut James, insting ialah suatu alat yang dapat menimbulkan perbuatan yang menyampaikan pada tujuan dengan berpikir lebih dahulu kearah tujuan itu dan tiada dengan didahului latihan perbuatan itu.

b. Pola Dasar Bawaan (Turunan)

Pada awal perkembangan kejiwaan primitif, bahwa ada pendapat yang mengatakan kelahiran manusia itu sama. Dan yang membedakan adalah faktor pendidikan. Tetapi pendapat baru mengatakan tidak ada dua orang yang ke luar di alam keujudan sama dalam tubuh, akal dari akhlaknya. Ada teori yang mengemukakan masalah turunan (bawaan), yaitu: Turunan (Pembawaan) dan Sifat-sifat bangsa.

c. Lingkungan

Lingkungan ialah suatu yang melingkungi tubuh yang hidup. Lingkungan tumbuh-tumbuhan oleh adanya tanah dan udaranya, lingkungan manusia ialah apa yang melingkunginya dari negeri, lautan, sungai, udara dan bangsa. Lingkungan ada dua macam yaitu: Lingkungan Alam dan Lingkungan Pergaulan.

d. Kebiasaan

Kebiasaan ialah perbuatan yang diulang-ulang terus sehingga mudah dikerjakan bagi seseorang. Seperti kebiasaan berjalan, berpakaian, berbicara, berpidato, mengajar, dan lain sebagainya. Orang berbuat baik atau buruk karena dua faktor dari kebiasaan yaitu: kesukaan hati terhadap suatu pekerjaan; menerima kesukaan itu, yang akhirnya menampikkan perbuatan. Dan diulang-ulang terus menerus.

e. Kehendak

Suatu perbuatan ada yang berdasar atas kehendak dan bukan hasil kehendak. Contoh yang berdasarkan kehendak adalah menulis, membaca, mengarang atau berpidato dan lain sebagainya. Adapun contoh yang berdasarkan bukan kehendak adalah detik hati, bernafas dan gerak mata.

f. Pendidikan 
Dunia pendidikan sangat besar pengaruhnya terhadap perubahan perilaku, akhlak seseorang. Berbagai ilmu diperkenalkan agar siswa memahaminya dan dapat melakukan suatu perubahan pada dirinya. Semula anak belum tahu perhitungan, setelah memasuki dunia pendidikan sedikit banyak mengetahui. Kemudian dengan bekal ilmu tersebut, mereka memiliki wawasan luas dan diterapkan ke hal tingkah laku ekonomi. Begitu pula apabila, siswa diberi pelajaran "Akhlak", maka memberitahu bagaimana seharusnya manusia itu bertingkah laku, bersikap terhadap sesamanya dan Penciptanya (Tuhan). ${ }^{31}$

Akhlak terbagi menjadi tiga yaitu: Akhlak kepada Allah dan Rasul, kepada sesama manusia, dan kepada alam semesta.

a. Akhlak Kepada Allah dan Rasul

Akhlak kepada Allah, adalah selalu merasa kehadiran Allah dalam kehidupan manusia. Firman Allah SWT dalam surah Al-Baqarah ayat 186 yang menerangkan bahwa Allah berada dekat dengan hamba-hamba-Nya dan akan mengabulkan do'a orang-orang yang berdo'a.

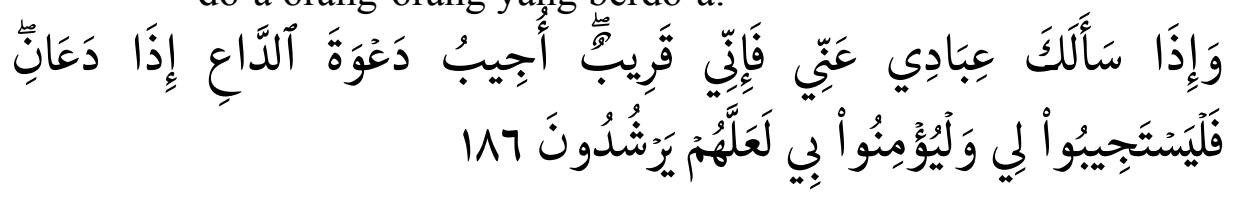

Artinya: "Dan apabila hamba-hamba-Ku bertanya kepadamu tentang Aku, maka (jawablah), bahwasanya Aku adalah dekat. Aku mengabulkan permohonan orang yang berdoa apabila ia memohon kepada-Ku, maka hendaklah mereka itu memenuhi (segala perintah-Ku) dan hendaklah mereka beriman kepada-Ku, agar mereka selalu berada dalam kebenaran". (QS. al-Baqarah [2]: 186) ${ }^{32}$

31 Mustofa, Akhlak Tasawuf, Op.Cit., hal. 82

32 El-Qurtuby, Usman, Andi Subarkah, 2012, Al-Qur'an \& Terjemah Tajwid, Bandung: Cordoba. 
b. Akhlak Kepada Manusia

1) Akhlak Kepada Diri Sendiri

Akhlak kepada diri memenuhi kewajiban dan hak diri, ditunaikan kewajiban dan dimanfaatkan atau diambil hak. Seluruh anggota tubuh manusia mempunyai hak dan harus ditunaikan. Disinilah terkait dengan pemeliharaan diri agar sehat jasmani dan rohani menunaikan kebutuhan diri, baik yang bersifat biologis maupun spiritual.

2) Akhlak Kepada Keluarga

Dimulai dari akhlak kepada orang tua, berbuat baik seperti yang tertera pada surah Luqman ayat 14

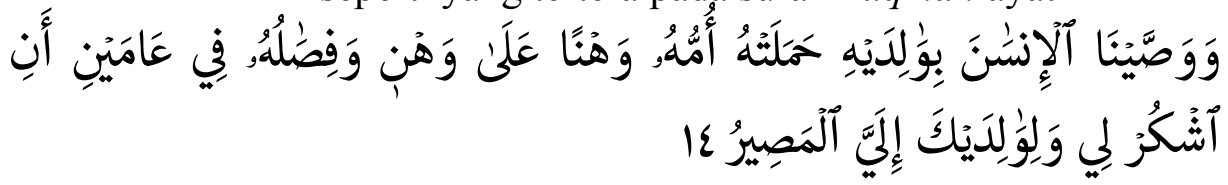

Artinya: "Dan Kami perintahkan kepada manusia (berbuat baik) kepada dua orang ibu-bapaknya; ibunya telah mengandungnya dalam keadaan lemah yang bertambah-tambah, dan menyapihnya dalam dua tahun. Bersyukurlah kepada-Ku dan kepada dua orang ibu bapakmu, hanya kepada-Kulah kembalimu". (QS. Luqman [31]: 14) 33

3) Akhlak Kepada Tetangga

Rasul sangat memberi perhatian tentang masalah yang berkenaan dengan "jiran" atau tetangga, sehingga begitu tinggi perhatian yang diajarkan Nabi untuk menghormati dan menyayangi tetangga.

4) Akhlak Kepada Masyarakat Luas

Akhlak terhadap masyarakat menyangkut bagaimana menjalin ukhuwah, menghindarkan diri dari perpecahan serta saling bermusuhan.

c. Akhlak Kepada Alam Semesta

Akhlak terhadap alam semesta, terkait erat dengan fungsi manusia sebagai khalifah Allah di Bumi. Fungsi

33 El-Qurtuby, Usman, Andi Subarkah, 2012, Al-Qur'an \& Terjemah

Tajwid, Bandung: Cordoba. 
Thorigotuna | Jurnal Pendidikan Islam

kekhalifahan manusia itu terkait dengan eksploitasi kekayaan alam semesta. $^{34}$

\section{Karakteristik Siswa}

Setiap individu memiliki ciri, sifat bawaan (heredity), dan karakteristik yang diperoleh dari pengaruh lingkungan sekitarnya. Ahli psikologi berpendapat bahwa kepribadian dibentuk oleh perpaduan faktor pembawaan dan lingkungan. Karakteristik bawaan, baik yang bersifat biologis maupun psikologis, dimiliki sejak lahir. Apa yang dipikirkan, dikerjakan atau dirasakan seseorang, atau merupakan hasil perpaduan antara apa yang ada di antara faktor-faktor biologis yang diwariskan dan pengaruh lingkungan sekitarnya. Tanpa memedulikan umur seorang anak, karakteristik pribadi yang dibawa ke sekolah terbentuk dari pengaruh lingkungan. Hal itu berpengaruh cukup besar terhadap keberhasilan atau kegagalannya di sekolah dan pada masamasa perkembangan selanjutnya. Karakteristik yang berkaitan dengan perkembangan faktor biologis cenderung lebih bersifat tetap (ajeg), sedangkan karakteristik yang berkaitan dengan faktor psikologis lebih mudah berubah karena dipengaruhi oleh pengalaman dan lingkungan. ${ }^{35}$

Siswa Sekolah Menengah Pertama atau Madrasah Tsanawiyah pada umumnya adalah siswa usia remaja. Remaja sebagai periode tertentu dari kehidupan manusia merupakan suatu konsep yang relatif baru dalam kajian psikologi. Menurut Abin Syamsuddin Makmun, perilaku dan pribadi siswa MTs atau SMP sudah memasuki masa remaja. Hal ini dijelaskan lebih lanjut bahwa rentangan masa remaja itu berlangsung dari sekitar 11-13 tahun sampai 18-20 tahun menurut umur kalender kelahiran seseorang. Masa remaja terbagi menjadi dua, yaitu masa remaja awal (usia 11-13 tahun sampai 14-15 tahun) dan masa remaja akhir (usia 14-16 tahun sampai 18-20 tahun). ${ }^{36}$ Dengan demikian siswa MTs atau SMP yang dijadikan subyek penelitian penulis termasuk

34 Haidar Putra Daulay, Pendidikan Islam Dalam Perspektif Filsafat, Op. Cit., hal. 136-140

35 Enung Fatimah Psikologi Perkembangan, Op.Cit., hal 12

36 Abin Syamsuddin Makmun, Psikologi Remaja, (Jakarta: Rineka Cipta, 2004), hal. 78-79 
dalam golongan masa remaja awal. Karena pada masa remaja ini seorang siswa akan lebih senang mencontoh dan mengikuti zaman. Maka dari itu seorang guru harus bisa menjadi pembimbing yang baik supaya bisa mengarahkan siswanya berprilaku yang baik atau memiliki akhlak mahmudah.

Dalam buku-buku psikologi perkembangan, berdasarkan usianya siswa MTs atau SMP dimasukkan ke dalam kategori remaja awal, yaitu dengan usia berkisar antara 12-15 tahun. Menurut Sri Rumini, dkk, karakteristik remaja awal diantaranya:

a. Keadaan Perasaan dan Emosi

Keadaan perasaan dan emosinya sangat peka sehingga tidak stabil. Staniey Hall menyebutkan: "storm and stress" atau badai dan topan dalam kehidupan perasaan dan emosi. Remaja awal dilanda pergolakan sehingga selalu mengalami perubahan dalam perbuatannya.

b. Keadaan Mental

Kemampuan mental khususnya kemampuan berpikirnya mulai sempuna dan kritis (dapat melakukan abstraksi). Ia mulai menolak hal-hal yang kurang dimengerti. Maka sering terjadi pertentangan dengan orang tua, guru, maupun orang dewasa lainnya.

c. Keadaan Kemauan

Kemauan dan keinginan mengetahui berbagai hal dengan jalan mencoba segala hal yang dilakukan orang lain.

d. Keadaan Moral

Pada awal remaja, dorongan seks sudah cenderung memperoleh pemuasan sehingga mulai berani menunjukkan sikap-sikap agar menarik perhatian.

\section{HASIL DAN PEMBAHASAN}

Hasil analisis deskriptif menunjukkan nilai Mean $=56$ nilai Median $=58$ dan nilai Modus $=59$. Ketiganya hampir memiliki nilai yang sama, yang berarti etika guru di MTs Rihlatul Ummah dikatakan baik. Akhlak siswa di MTs Rihlatul Ummah juga dikategorikan baik. Hal ini terbukti dari hasil perhitungan nilai mean $=57$, nilai median $=$ 
57, dan nilai modus $=56$. Selanjutnya menghitung nilai korelasi dengan rumus:

$$
\begin{aligned}
r_{x y} & =\frac{n \sum X Y-\left(\sum X\right)\left(\sum Y\right)}{\sqrt{\dot{i} \dot{i}}} \\
r_{x y} & =\frac{75.243312-(4245)(4283)}{\sqrt{\left\{75.244347-\left(4245 \dot{i}^{2}\right\} \mid 75.247801-\left(4283 i^{2}\right\}\right.}} \\
r_{x y} & =\frac{18248400-18181335}{\sqrt{|18326025-18020025|(18585075-18344089)}} \\
r_{x y} & =\frac{67065}{\sqrt{|306000|\{240986)}} \\
r_{x y} & =\frac{67065}{\sqrt{7374171600}} \\
r_{x y} & =\frac{67065}{85872,9} \\
r_{x y} & =0,78
\end{aligned}
$$

Korelasi dilambangkan dengan (r) dengan ketentuan nilai $\mathrm{r}$ tidak lebih dari harga $(-1 \leq \mathrm{r} \leq+1)$. Apabila nilai $\mathrm{r}=-1$ artinya korelasinya negatif sempurna; $r=0$ artinya tidak ada korelasi; dan $r=$ 1 berarti korelasinya sangat kuat.

Hasil perhitungan diatas diperoleh nilai koefisien korelasi dasar $r=0,78$. Nilai koefisien korelasi tersebut memiliki korelasi yang tinggi atau kuat. Nilai yang tinggi atau kuat tersebut mengandung arti atau menunjukkan bahwa etika guru memiliki pengaruh yang kuat terhadap akhlak siswa, sesuai dengan keterangan diatas.

Langkah selanjutnya ialah pengujian hipotesis. Pengujian hipotesis ini dimaksudkan untuk menentukan kesimpulan, apakah hipotesis yang diajukan yaitu etika guru mempunyai pengaruh yang signifikan terhadap akhlak siswa. Sehingga dapat diketahui apakah hipotesis tersebut diterima atau ditolak.

Langkah-langkah pengujian hipotesis untuk membuat kesimpulan dari hipotesis yang diajukan adalah sebagai berikut:

a) Perumusan hipotesis nol yang di uji

$\mathrm{H}_{\mathrm{o}}=\mathrm{r}_{\mathrm{xy}}=0 \quad$ : Tidak ada pengaruh yang signifikan antara etika guru terhadap akhlak siswa 
$\mathrm{H}_{\mathrm{a}}=\mathrm{r}_{\mathrm{xy}}=0 \quad$ : Adanya pengaruh yang signifikan antara etika guru terhadap akhlak siswa

b) Tes Signifikansi

Tes signifikansi dimaksudkan untuk mencari nilai $\mathrm{t}_{\text {hitung }}$ yang hasilnya akan dibandingkan dengan nilai $t_{\text {tabel }}$ untuk menentukan kesimpulan. Adapun rumus yang digunakan dalam perhitungan nilai ini adalah:

$$
\begin{aligned}
& t_{\text {hitung }}=\frac{r \sqrt{n-2}}{\sqrt{1-r^{2}}} \\
& t_{\text {hitung }}=\frac{0,78 \sqrt{75-2}}{\sqrt{1-0,6084}} \\
& t_{\text {hitung }}=\frac{0,78 \sqrt{73}}{\sqrt{0,3916}} \\
& t_{\text {hitung }}=\frac{0,78.8,54}{0,6258} \\
& t_{\text {hitung }}=\frac{6,6612}{0,6258} \\
& t_{\text {hitung }}=10,64
\end{aligned}
$$

c) Menentukan $t_{\text {tabel }}$ dan derajat signifikansi (db) dengan taraf kesalahan 5\%:

$$
\begin{aligned}
\mathrm{db} \quad & \mathrm{n}-2 \\
= & 75-2 \\
= & 73 \\
& >\quad \mathrm{t}_{\text {tabel }} \\
\mathrm{t}_{\text {hitung }} & >\quad(1,67)
\end{aligned}
$$

Dari hasil perhitungan diatas, maka dapat diperoleh nilai dari hasil $t_{\text {tabel }}$ pada taraf kesalahan 5\% sebesar 1,67. Hal ini berarti $t_{\text {hitung }}$ lebih besar dari $t_{\text {tabel }}\left(t_{\text {hitung }}>t_{\text {tabel }}\right)$, maka dapat disimpulkan bahwa $r_{\mathrm{xy}}$ dari hasil indeks koefisien korelasi terdapat korelasi positif yang signifikan, artinya variabel $\mathrm{X}$ yaitu etika guru mempunyai pengaruh yang signifikan dengan variabel $\mathrm{Y}$ yaitu akhlak siswa. 
Untuk mengetahui besarnya nilai pengaruh antara variabel $\mathrm{X}$ terhadap variabel $\mathrm{Y}$ tersebut maka dilakukan perhitungan koefisien determinan dengan rumus:

$\mathrm{KD}=\mathrm{r}^{2} \times 100 \%$

$\mathrm{KD}=(0,78)^{2} \times 100 \%$

$\mathrm{KD} \quad=0,61 \times 100 \%$

$\mathrm{KD} \quad=61 \%$

Berdasarkan perhitungan diatas, diketahui bahwa terdapat $61 \%$ pengaruh etika guru (variabel X) terhadap akhlak siswa (variabel $\mathrm{Y})$ terjadi korelasi yang sangat kuat, dengan dimana sisanya $39 \%$ dipengaruhi oleh faktor lain.

\section{KESIMPULAN}

Berdasarkan hasil penelitian yang dilakukan mengenai etika guru terhadap akhlak siswa di MTs Rihlatul Ummah maka penulis dapat mengambil kesimpulan sebagai berikut:

a. Etika guru dengan siswa di MTs Rihlatul Ummah dikategorikan baik. Hal ini terbukti dari hasil perhitungan variabel $\mathrm{X}$ dengan nilai mean 56, nilai median 58, dan nilai modus 59 .

b. Akhlak siswa di MTs Rihlatul Ummah dikategorikan baik. Hal ini terbukti dari hasil perhitungan variabel Y dengan nilai mean 57, nilai median 57, dan nilai modus 56 .

c. Terdapat pengaruh yang positif dan signifikan antara etika guru dengan akhlak siswa di MTs Rihlatul Ummah dengan tingkat koefisien korelasi sebesar 0,78 (kuat). Hal ini terbukti dengan derajat signifikansi yaitu $t_{\text {tabel }}$ pada taraf signifikansi 5\% sebesar 1,67 dan $t_{\text {hitung }} 10,64$ yang berarti $t_{\text {hitung }}$ lebih besar dari $t_{\text {tabel }}\left(t_{\text {hitung }}\right.$ $\left.>\mathrm{t}_{\text {tabel }}\right)$. Adapun kontribusi variabel $\mathrm{X}$ dengan variabel $\mathrm{Y}$ sebesar $61 \%$, artinya $61 \%$ akhlak siswa di MTs Rihlatul Ummah berhubungan dengan etika guru.

\section{DAFTAR PUSTAKA}

A. Muri Yusuf. Metode Penelitian Kuantitatif Kualitatif dan Penelitian Gabungan. Jakarta: Kencana. 2014. 
Abin Syamsuddin Makmun. Psikologi Remaja. Jakarta: Rineka Cipta. 2004.

Anwar Rosihan. Akhlak Tasawuf. Bandung: CV Pustaka Setia. 2010.

El-Qurtuby, Usman dan Andi Subarkah. Al-Qur'an \& Terjemah Tajwid, Bandung: Cordoba. 2012

Djabidi Faisal. Manajemen Pengelolaan Kelas. Malang: Madani. 2016.

Fatimah Enung. Psikologi Perkembangan. Bandung: CV Pustaka Setia. 2010.

Hasbullah. Dasar-Dasar Ilmu Pendidikan. Jakarta: PT RajaGrafindo Persada. 2012.

Munzier Suparta. Metodologi Pengajaran Agama Islam. Jakarta: Aniscol. 2003.

Mustofa. Akhlak Tasawuf. Bandung: CV Pustaka Setia. 2010.

Ondi Saondi dan Aris Suherman, Etika Profesi Keguruan. Bandung: PT

Refika Aditama. 2010.

Putra Daulay Haidar. Pendidikan Islam Dalam Perspektif Filsafat.

Jakarta: Kencana. 2014.

http://www.makalahku.online/2017/03/hadis-tentang-etika-guruterhadap-siswa.html. 